University of Nebraska - Lincoln

DigitalCommons@University of Nebraska - Lincoln

Mammalogy Papers: University of Nebraska

State Museum

Museum, University of Nebraska State

$1-1-1971$

\title{
Bacula of Some Neotropical Bats
}

\author{
Randall E. Brown \\ Oregon State University, Corvallis
}

Hugh H. Genoways

University of Nebraska - Lincoln, h.h.genoways@gmail.com

J. Knox Jones Jr.

University of Kansas

Follow this and additional works at: https://digitalcommons.unl.edu/museummammalogy

Part of the Zoology Commons

Brown, Randall E.; Genoways, Hugh H.; and Jones, J. Knox Jr., "Bacula of Some Neotropical Bats" (1971). Mammalogy Papers: University of Nebraska State Museum. 85.

https://digitalcommons.unl.edu/museummammalogy/85

This Article is brought to you for free and open access by the Museum, University of Nebraska State at DigitalCommons@University of Nebraska - Lincoln. It has been accepted for inclusion in Mammalogy Papers: University of Nebraska State Museum by an authorized administrator of DigitalCommons@University of Nebraska Lincoln. 


\title{
BACULA OF SOME NEOTROPICAL BATS
}

\author{
by
}

Randall E. Brown, Hugh H. Genoways and J. Knox Jones, Jr.

Les auteurs ont recherché la présence d'un baculum chez 56 espèces de chauves-souris appartenant à 5 familles différentes. Les Noctilionidés et les Phyllostomatidés (sensu lato) examinés n'ont pas d'os pénien mais on rencontre cet os chez toutes les espèces étudiées des Emballonuridés, Natalidés et Vespertilionidés. Les bacula de 7 Emballonuridés, d'un Natalidé et de 7 Vespertilionidés sont figurés et brièvement décrits.

Bacular morphology long has interested mammalogists and has proved useful taxonomically in many mammalian groups. Some species or groups of mammals lack bacula and this fact, too, has been of aid in documenting relationships (or lack of them), particularly among higher taxa. Some chiropteran bacula have been studied (see Brown, 1967, for review of the pertinent literature), but among New World bats few data have been published on other than temperate species. In the course of recent studies of the bacula of New World molossids (Brown, op. cit.), we took the opportunity to clear and stain the penes of a number of Neotropical species of other chiropteran families in search of comparative material. While preliminary in nature, this survey resulted in considerable evidence relating to bacula and is summarized here.

Species of bats examined in this study are listed in Table 1. All emballonurids, natalids, and vespertilionids examined possessed bacula, which are figured and briefly described beyond. It is significant that members of the families Noctilionidae and Phyllostomatidae (sensu lato, including chilonycterines and desmodontines) lack an os penis. It will be remembered that the noctilionids have been aligned by some authors with the Superfamily Emballonuroidea, but the presence of a well-developed baculum in at least the New World emballonurids places this relationship in question.

Methods and procedures are those outlined by Brown (1967), and all measurements of bacula are in millimeters and are of adults. Catalogue numbers of specimens listed relate to the collections of the Museum of Natural History at Kansas. 
TABLE 1

Neotropical bats examined in this study

Species (number examined) Baculum present Baculum absent

Family EMBALLONURIDAE

Rhynchonycteris naso (1)

Saccoptergx bilineata (1)

Cormura brevirostris (1)

Peropteryx macrotl: (2)

Peroptergx kappleri (1)

Balantiopteryx plicata (2)

Balantioptergx io (2)

$\mathrm{x}$

$\mathrm{x}$

$\mathrm{x}$

$\mathbf{X}$

$\mathbf{X}$

$\mathrm{X}$

$\mathrm{x}$

Family NOCTILIONIDAE

Noctilio labialis (2)

Noctilio leporinus (2)

$\mathbf{x}$

$\mathbf{X}$

Family PHYLLOSTOMATIDAE

Subfamily ChILonycterinae

Pteronotus parnellii (5)

Pteronotus davyi (8)

Pteronotus suapurensis (10)

Mormoops megalophylla (3)

$\mathrm{x}$

$\mathrm{x}$

$\mathrm{x}$

$\mathrm{X}$

Subfamily Phyllostomatinae

Micronycteris megalotis (1)

Micronycteris sylvestris (1)

$\mathrm{X}$

Macrotus waterhousin (1)

Lonchorhina aurita (1)

Tonatia sylvicola (1)

Mimon cozumelae (1)

Phyllostomus hastatus (3)

Phyllostomus discolor (1)

Trachops cirrhosus (3)

Chrotopterus auritus (1)

Vampyrum spectrum (1)

Subfamily GLossophaginaE

Glossophaga soricina (3)

Lonchophylla robusta (5)

Monophyllus plethodon (1)

Anoura geoffroyi (1)

Choeronycteris mexicana (1)

Leptonycteris sanborni (4)

Leptonycteris curasoae (1)

$\mathrm{x}$

$\mathrm{x}$

$\mathrm{x}$

$\mathrm{x}$

$\mathrm{x}$

$\mathrm{x}$

$\mathrm{x}$

$\mathrm{X}$

$\mathrm{x}$

$\mathrm{x}$

Subfamily Carolinae

Carollia perspicillata (5)

$\mathrm{x}$

$\mathrm{x}$

$\mathrm{x}$

$\mathrm{x}$

$\mathrm{x}$

$\mathrm{X}$

$\mathrm{X}$

X 


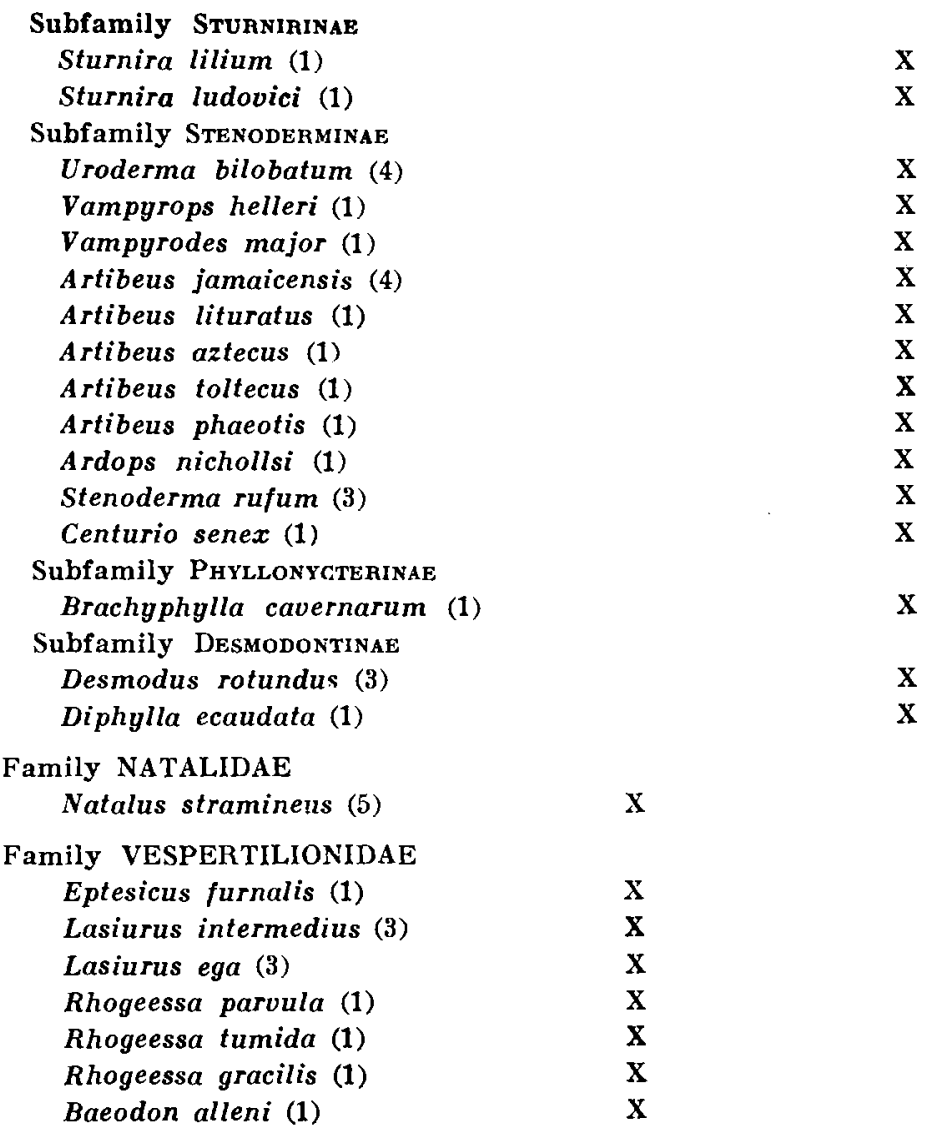

Family EMBALLONURIDAE

Rhynchonycteris naso Wied-Neuwied, 1820

(Fig. 1)

Specimen examined (1). - Nicaragua (96224). .30 .

Measurements. - Greatest lenght, .80 ; greatest breadth at base,

Remarks. - In dorsal aspect, the baculum of this species flares outward from the base, narrows medially, and expands toward the rounded, distal end. In lateral aspect, the basal end is concave, the central portion irregularly constricted, and the blunt distal end enlarged. The os penis of $R$. naso is considerably larger than that of any other emballonurid examined. 

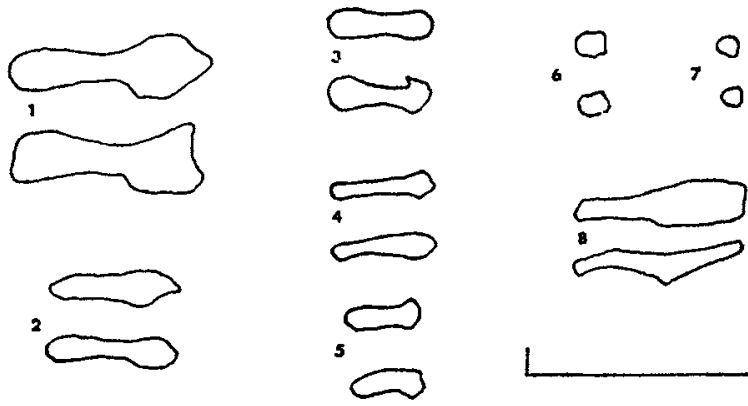

Fig. 1-8. - Dorsal (above) and lateral views of bacula of seven species of New World emballonurids and Natalus stramineus. The scale at lower right is one millimeter long.

1, Baculum of Rhynchonycteris naso (96224). 2, Baculum of Saccopteryx bilineata (76594). 3, Baculum of Cormura brevirostris (93898). 4, Baculum of Peropteryx macrotis (93212). 5, Baculum of Peropteryx kappleri (102261). 6 , Baculum of Balantiopteryx plicata (60576). 7, Baculum of Balantiopteryx io (30781). 8, Baculum of Natalus stramineus (39622).

Saccopteryx bilineata Temminck, 1838

(Fig. 2)

Specimen examined (1). - Trinidad (76594).

Measurements. - Greatest length, .57 ; greatest breadth at base, .18.

Remarks. - In dorsal aspect, the relatively large baculum of S. bilineata flares outward from a pointed base and then tapers gradually to a bluntly pointed distal end. In lateral aspect, the base and distal end are broadly rounded ; the bone is constricted medially.

Cormura brevirostris (Wagner, 1843)

(Fig. 3)

Specimen examined (1). - Canal Zone (93898).

Measurements. - Greatest length, .40 ; greatest breadth at base, .10.

Remarks. - the baculum is rounded at each end and constricted medially in both dorsal and lateral aspects in this species. In both views, the distal end is slightly broader than the base. The hook on the dorsal part of the base may represent an individual variation.

Peropteryx macrotis (Wagner, 1821)

(Fig. 4)

Specimens examined (2). - Yucatan (93211-12).

Measurements. - Greatest length, .36 (.30-.42) ; greatest breadth at base, .11 (.09-.13). 
Remarks. - In lateral aspect, the base of the os penis of this bat is obtusely pointed ; the bone is constricted medially and rounded distally. It is rounded at each end in lateral aspect, constricted medially, and slightly bowed dorsad.

\section{Peropteryx kappleri Peters, 1867 (Fig. 5)}

\section{Specimen examined (1). - Chiapas (102261).} .12 .

Measurements. - Greatest length, .30 ; greatest breadth at base,

Remarks. - The baculum of P. kappleri is shorter and stouter than that of $P$. macrotis, but otherwise resembles it.

Balantiopteryx plicata Peters, 1867

(Fig. 6)

Specimens examined (2). - Sinaloa (60576, 95654).

Measurements. - Greatest length, .07 (.03-.10) ; greatest breadth at base, .06 (.03-.08).

Remarks. - The baculum of $B$. plicata is flat basally and rounded distally. The bone is extremely small in both species of Balantiopteryx and probably variable in shape and size. For example, in one specimen (60576) - the one figured-the baculum is larger than those of the two examples of $B$. io examined, whereas the baculum of another specimen (95654) is much smaller.

\section{Balantiopteryx io Thomas, 1904}

(Fig. 7)

Specimens examined (2). - Veracruz $(30779,30781)$.

Measurements. - Greatest length, .08 (.07-.08) ; greatest breadth at base, .09 (.08-.09).

Remarks. - The small baculum is flat basally and rounded distally as in $B$. plicata.

\section{Family NATALIDAE \\ Natalus stramineus Gray, 1838}

(Fig. 8)

Specimen examined (1). - Sinaloa (39622).

Measurements. - Greatest length, .70 ; greatest breadth at base, .19 .

Remarks. - The baculum of this species has an irregular outline in lateral view. The bone tapers toward either end. In dorsal 
aspect, the basal half is broad and squared, whereas the distal half is narrow and rodlike. The baculum of the specimen measured and figured is similar in size and shape to those of four others examined from Sinaloa.

\section{Family VESPERTILIONIDAE}

Eptesicus furinalis (D'Orbigny, 1847)

(Fig. 9)

\section{Specimen examined (1). - Nicaragua (111231).}

Measurements. - Greatest length, .92 ; greatest breadth at base, .65 .

Remarks. - The os penis of E. furinalis is broad basally and rounded at the basal end in dorsal view ; ventrally it is markedly convex beneath the basal flanges. The distal end is blunt and connected with the base by a triangular-shaped neck. In lateral view, the distal end is somewhat knoblike ; basally, the broad flanges
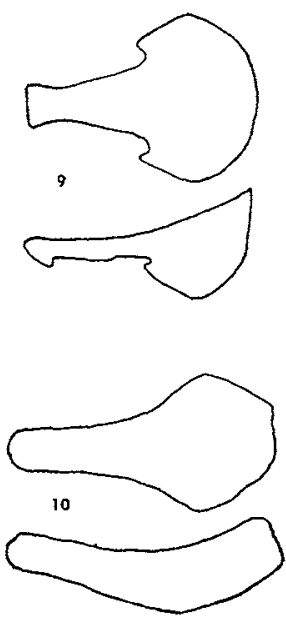

17

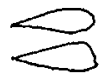

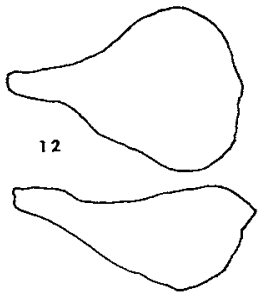
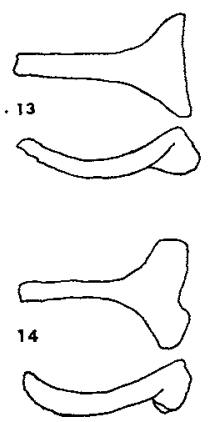
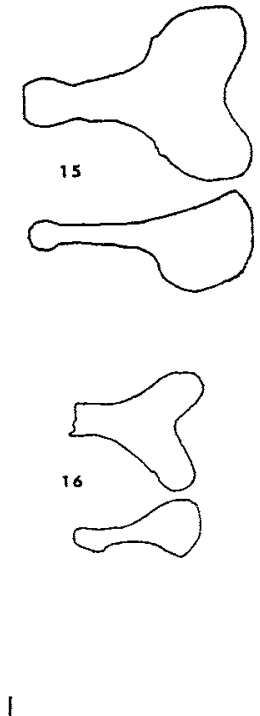

Fig, 9-16. - Dorsal (above) and lateral views of bacula (and one os clitoridis) of seven Neotropical vespertilionids. The scale at lower right is one millimeter long.

9, Baculum of Eptesicus furinalis (111231). 10, Baculum of Lasiurus intermedius (55317). 11, Os clitoridis of Lasiurus intermedius (67540). 12, Baculum of Lasarius ega (94346). 13, Baculum of Rhogeessa parvula (61163). 14, Baculum of Rhogeessa tumida (82922). 15, Baculum of Rhogeessa gracilis (108976). 16, Baculum of Baeodon alleni (61170). 
extend laterad and ventrad, whereas the dorsal aspect rises sharply, forming a "saddle " over the marked ventral convexity through which the urethra passes.

The baculum of this species is much larger and more noticeably sculptured than that of Eptesicus fuscus as described and figured by Hamilton (1949:98, 100), and lacks a basal emarignation.

\section{Lasiurus intermedius $\mathrm{H}$. Allen, 1862}

(Figs. 10-11)

Specimens examined (3). - Tamaulipas (55317, 55324, 55322).

Measurements. - Greatest length, 1.22 (1.15-1.35) ; greatest breadth at base, .59 (.52-.65).

Remarks. - The baculum of this yellow bat bows ventrad. Broad, lateral flanges arise from the basal half and extend ventrad on either side of the urethra. In dorsal aspect, the basal half of the baculum is roughly hexagonal and the narrow distal end is rounded. Our specimens generally resemble (but are not so markedly concave dorsally) the one Floridian specimen of $L$. intermedius described and figured by Hamilton (1949:98, 101).

One female (67540 from Veracruz) was examined and found to contain an os clitoridis (Fig. 11) that measured .30 in greatest length and .09 across the base. The bone is teardrop-shaped and asymmetrical in lateral aspect ; the sharp distal third is unossified.

\section{Lasiurus ega (Gervais, 1856)}

(Fig. 12)

Specimens examined (3). - Baja California del Sur (94342, 94346) and Zacatecas (57968).

Measurements. - Greatest length, .95 (.76-1.20) ; greatest breadth at base, .69 (.51-.82).

Remarks. - The baculum of $L$. ega differs from that of $L$. intermedius chiefly in the greater expansion of the lateral flanges laterad and ventrad. An os clitoridis was not found in one female examined.

Rhogeessa parvula $\mathrm{H}$. Allen, 1866

(Fig. 13)

Specimen examined (1). - Sinaloa (61163).

Measurements. - Greatest length, .73 ; greatest breadth at base, .41 . 
Remarks. - The central rib of the baculum of this species is a rounded rod that is bowed ventrad. Lateral flanges arise near the base and curve ventrad. In dorsal aspect, the base appears concave. The sharp-tipped flanges taper rapidly toward the central rib.

Rhogeessa tumida H. Allen, 1866

(Fig. 14)

Specimen examined (1). - Veracruz (82922).

Measurements. - Greatest length, .67; greatest breadth at base, .43.

Remarks. - The central rib is slightly compressed laterally. The lateral flanges are round-tipped, and the base is irregularly concave in dorsal aspect. Otherwise the baculum of $R$. tumida is similar to that of $R$. parvula.

\section{Rhogeessa gracilis Miller, 1897}

(Fig. 15)

Specimen examined (1). - Jalisco (108976).

Measurements. - Greatest length, .87 ; greatest breadth at base, .68 .

Remarks. - The os penis of $R$. gracilis is much broader and longer than that of the other two species of Rhogeessa, resembling in shape (although larger than) the baculum of Baeodon alleni. The distal end is knoblike. The base is broadly flared laterad and ventrad over the urethral passage, and is emarginate in dorsal view.

Baeodon alleni (Thomas, 1892)

(Fig. 16)

Specimen examined (1). - Oaxaca (61170).

Measurements. - Greatest length, .50 ; greatest breadth at base, .47 .

Remarks. - In dorsal aspect, the baculum of Baeodon is broadly Y-shaped, with rounded arms and blunt base. Broad, ventrallydirected flanges arise from the bowed basal portion. The baculum is constricted medially and the distal tip is swollen. Viewed laterally, the tips of the lateral flanges are somewhat pointed.

\section{SUMMARY}

Neotropical bats representing 56 species of five families were examined for presence or absence of a baculum. Members of the families Noctilionidae and Phyllostomatidae (sensu lato) have no os penis, but the bone was found in 
all species studied of Emballonuridae, Natalidae, and Vespertilionidae. The bacula of seven emballonurids, one natalid, and seven vespertilionids are briefly described and figured.

Department of Zoology, Oregon State University, Corvallis, and Museum of Natural History, The University of Kansas, Lawrence, U.S.A.

\section{BIBLIOGRAPHY}

Bnown, R. E., 1967. - Bacula of some New World molossid bats. Mammalia, $31: 645-667$.

Hamilton, W. J., Jr., 1949. - The bacula of some North American vespertilionid bats. Jour. Mamm., 30 : 97-102. 